\title{
Factors That Back Up Taxes For Micro, Small And Medium Enterprises (MSMEs) In Taking The Tax Evasion In Indonesia
}

\author{
Sonny, SE., BKP \\ Institut STIAMI \\ stellayoung1881@yahoo.com \\ DOI: 10.29322/IJSRP.11.07.2021.p11575 \\ http://dx.doi.org/10.29322/IJSRP.11.07.2021.p11575
}

\begin{abstract}
The needs of local governments to the central government in terms of financing and the level of public compliance in paying taxes in accordance with what is owed are the focus that needs to be discussed. For this reason, this study aims to analyze the factors that encourage tax evasion according to individual taxpayers in City X. This type of research is descriptive qualitative, and the data used are primary data. Data obtained through direct interviews with seven informants in $\mathrm{X}$ city based on the results of research on the analysis of the factors that encourage tax evasion in the form of reduction, elimination, and manipulation of tax burdens illegally according to taxpayers in City X, it can be concluded that the driving factor for people to commit tax evasion These are the tariff factors that make the tax burden high, the economic factor, the tax system factor that is too complicated, the compliance factor which aims to enrich themselves, the government assertiveness factor and the distrust of the government bureaucracy.
\end{abstract}

Keywords: Taxes, Factors, Tax Avoidance.

\section{INTRODUCTION}

Indonesia is a developing country that still needs support from the community to become a developed country. Not just support for ideas, but society needs to be a source of state revenue through tax payments. This is because taxes are the main source of state revenue which is used to finance state expenditures to meet community needs and carry out development. Both of these things, of course, require a lot of funds. According to Nastiti, FA (2019) the definition of tax is the contribution paid to the state (which can be enforced) owed by those who are obliged to pay based on regulations with no return, which can be directly appointed and used to finance general expenses related to duties. state to organize the government. Just imagine if taxes are not able to become the main actor of state revenue when the expectations of state revenue from taxes are very high, of course all the aspirations that all people in this country desire will be dashed and cause development to be left behind in all corners of the country. Therefore, all people who according to the law are taxpayers are obliged to pay taxes according to their obligations.

National growth itself has undergone drastic changes in the era of President Joko Widodo. However, foreign funding is still the dominant stepping stone in terms of development. This may indicate that taxes, which have been projected to be the main pillar of state revenue, have not yet become a major figure in state development independently. If all people obey to pay taxes, it will create a nation that is able to stand on its own feet where with this tax, the acceleration of development does not need to rely on foreign loans. In general, the domestic economy is still not improving, there are still some regions that are lagging behind in development, even though the government has made efforts to develop from remote parts of the country. Likewise with the political upheaval that affects the domestic economy, the inability of domestic resources in the world of work, to criminal acts of corruption that make people seem to have lost confidence in the government in paying taxes.

All efforts have been made by the government lately through the Directorate General of Taxes which schedules the expansion of tax subjects and objects or by capturing new taxpayers, especially Micro, Small and Medium Enterprises (MSMEs). With the issuance of Government Regulation Number 23 of 2018, broadening the tax subjects who need to pay their taxes. Several exceptions were abolished, such as an entrepreneur who finished selling and demolished his business premises and was not exempted from paying taxes. Traders in traditional markets as MSMEs are the subject of expansion of this regulation. In other efforts of the government to increase tax revenue, among others, by improving the quality of the tax apparatus, improving services, simplifying the rules and procedures for paying taxes, to increasing tax knowledge of taxpayers. The increase in NPWP holders is not directly proportional to state revenues. Therefore, it can be concluded that the increase in tax realization cannot be said to be immediately positive if all forms of tax evasion are still occurring in this country.

With the replacement of regional governments in Indonesia, it has entered a new stage with the implementation of Law no. 23 of 2014 concerning Regional Government which is a substitute for the previous Law, namely Law No. 32 of 2004 which is considered no longer in accordance with the times, developments in the situation, state administration and the demands of the 
administration of the Saudi government. In order to encourage the smooth implementation of regional autonomy, the central government has issued Law Number 33 of 2004 concerning Financial Balance between the Central and Regional Governments, so that the power of the planned fiscal decentralization is expected to be able to give freedom to the regions to manage and manage their own households. The Government of City X, like most other cities in Indonesia, which is currently in government administration, cannot be separated from central government subsidies in the form of the General Allocation Fund as can be seen in Table 1.

Table 1. Contribution of City X General Allocation Fund for Fiscal Year 2018-2020

\begin{tabular}{|c|c|c|}
\hline Fiscal year & General Allocation Fund & $\%$ Increase \\
\hline 2018 & $437.048 .958 .000,00$ & - \\
\hline 2019 & $582.867 .542 .000,00$ & $15.1 \%$ \\
\hline 2020 & $600.354 .000 .000,00$ & $6.7 \%$ \\
\hline
\end{tabular}

(Source: City Revenue Service X)

From Table 1 it can be seen that the development of the General Allocation Fund during the last three years has increased by $8.4 \%$. The data above shows that City X still has a high dependence on central government assistance. Tax support is needed for strategic funding. Taxes are closely related to regional development. However, tax barriers are seemingly endless. Because people, many people do not realize the importance of taxes as the main pillar of development.

Tax planning is one of the steps taken by taxpayers. Taxpayers try to reduce the tax owed in various ways. Tax avoidance and tax evasion are steps taken by taxpayers. Although both have the aim of reducing the tax burden, the characteristics of the two are very different. Tax Avoidance is an act of tax avoidance by exploiting loopholes in tax laws and regulations. Tax avoidance itself is a legal action in Indonesia. However, when it is difficult to do tax avoidance, people tend to take tax evasion actions to reduce the tax burden. Of course, the Tax Evasion action is something that aims to reduce the tax burden by violating tax laws and regulations in Indonesia.

The results of Hasibuan's (2014) study show that the perception of individual taxpayers regarding tax evasion is influenced by the intensity of tax audits, justice, taxpayer compliance, taxpayer knowledge, tax systems, discrimination, and the possibility of fraud detection. Spicer and Becker (1980) research found that factors demographics, namely gender affects the behavior of tax evasion. Based on previous studies, the researchers chose 5 (five) factors that may or may affect the perception of individual taxpayers regarding ethics on tax evasion, namely tax justice, tax systems, discrimination, knowledge of taxpayers, and intensity of tax audits. The reason the researchers chose these 5 (five) factors was because there were inconsistencies in the results of previous studies and there were factors that were rarely studied, such as taxpayers' knowledge and intensity of tax audits. Tax Service Office $\mathrm{X}$ is one of 8 (eight) Tax Service Offices operating under the Regional Tax Office X. The reason for conducting research at Tax Office X with Individual Taxpayers as respondents is because of the compliance level of individual taxpayers at the Tax Service Office X.

This research is expected to be able to provide practical and theoretical uses for the related parties. The practical use of this research is expected to be of benefit to the government, as input and consideration in understanding the effect of tax justice, taxation systems, discrimination, taxpayer knowledge, and the intensity of tax audits on individual taxpayers' perceptions of ethics on tax evasion. The theoretical usefulness of this research is expected to be useful for academics as a reference that the theory of perception can explain the effect of tax justice, taxation systems, discrimination, taxpayer knowledge, and tax audit intensity on individual taxpayers' perceptions of ethics on tax evasion. important aspects that determine how humans respond to the presence of various aspects and symptoms around them. Perception is also related to the way a person perceives a certain object in different ways by using their sense organs, then trying to interpret them.

Tax evasion is an effort to ease the tax burden by violating statutory provisions that can hinder state revenue (Xynas, 2011). Tax evasion refers to the improper actions taken by the taxpayer regarding their tax obligations. Taxpayers commit tax evasion by ignoring the formal provisions of taxation that are their obligations, falsifying documents, or filling in incomplete and incorrect data (Suminarsasi \& Supriyadi, 2011).

The principle of justice in essence views that taxation takes into account the rights and obligations of taxpayers. Several aspects of attitudes towards taxation, such as tax ethics and their perceptions of the fairness of the tax system also have an influence on the trend towards tax evasion (Jackson \& Milliron, 1986). Fairness is considered to be able to influence taxpayers' perceptions of ethics on tax evasion, which assesses that tax evasion is considered ethical due to the lack of fairness in the use of money that comes from taxes, government corruption, and does not get compensation / influence on taxes that have been paid, which results in a lack of fairness. the level of income of state tax revenues and causes a crisis of public confidence in related institutions in paying taxes (Mcgee, 2006). The taxation system is a method of how to manage tax debt owed by taxpayers so that it can flow to the state treasury. The Indonesian tax system, which now adopts self-assessment, gives taxpayers the freedom to be responsible for fulfilling their tax obligations. The tax apparatus also plays an active role in carrying out administrative control of tax collection which includes the tasks of guidance, service, supervision and application of tax sanctions (Rahman, 2013). 
The definition of discrimination is based on Law No.39 of 1999 on Human Rights article 1 paragraph (3). The law states that discrimination is any direct or indirect limitation, harassment or exclusion based on human differentiation on the basis of religion, ethnicity, race, ethnicity, group, class, social status, economic status, gender, language, political beliefs result in the reduction, deviation, or elimination of the recognition, implementation, or use of human rights and basic freedoms in life, both individually and collectively in the political, economic, legal, social, cultural and other aspects of life. If the level of discrimination in taxation is felt to be very high, the tendency of the public to carry out tax evasion will also increase. Taxpayers' knowledge includes knowledge of the concept of general provisions in the field of taxation, types of taxes that apply in Indonesia starting from tax subjects, tax objects, tax rates, tax calculations payable, recording payable tax, up to how to file tax reporting. In order to create tax compliance, taxpayers must know at least basic knowledge of taxation in relation to their personal income tax obligations (Choong \& Edward, 2011). Knowledge of taxpayers and prospective taxpayers will minimize the existence of tax evasion (Palil \& Kasipillai et al., 2005)

This also explains that the level of tax education and tax knowledge is very important to ensure that tax administration will run well (Palil \& Mohd, 2013). Even the most appropriate way to reduce tax evasion is to provide more tax knowledge to taxpayers to improve their tax ethics (Eriksen \& Lars, 1996). The definition of tax audit according to the KUP Law Number 28 of 2007 is a series of activities to collect and process data, information and audit evidence which are carried out objectively and professionally based on an audit standard to test compliance with the fulfillment of tax obligations and / or for other purposes in implementing the provisions.

Taxpayers who realize that they will not be detected committing fraud increasingly use a more complex tax evasion strategy so that fraud is increasingly difficult to track so that they can minimize the taxes they have to pay (Bergman, 1998). Increasing the intensity of tax audits can cause a decrease in tax evasion behavior, even this method is considered the most effective in encouraging taxpayer compliance (Alm \& McKee, 1992; Alm \& Schulze, 1992; Birskyte, 2013; Togler, 2002). Research by Kurniawati and Agus (2014) found that the tax justice variable has a negative and significant effect on taxpayers' perceptions of tax evasion.

\section{LITERATURE REVIEW}

\section{Tax Evasion}

In making tax payments, taxpayers must pay taxes correctly and in accordance with applicable laws but there are still many taxpayers who do not pay taxes according to their actual income and always commit tax evasion. According to Dewi, T. J., \& Merkusiwati, N. K. L. A. (2017) tax evasion is an effort made by taxpayers to ease the tax burden in a way that is illegal or violates the law. In this case, the taxpayer will ignore the formal provisions of taxation that are their obligation, falsify documents, or fill in incomplete and incorrect data (Friskianti, Y., \& Handayani, B. D., 2014).

\section{Tax accounting}

Accounting is a process of identifying, measuring, recording, reporting on financial transactions of an organization / entity that is used for information on economic decision-making for internal and external parties (Halim and Kusufi, 2014: 3). According to Sulistiani, I. (2016) taxes are people's contributions that are paid to the state treasury based on law (can be enforced) without receiving lead services (contrapretation) which can be directly demonstrated and which are used to pay for general expenses. Tax Function. There are two tax functions, namely:

(1) budget function (budgetair); and

(2) function regulating (cregulerend).

According to Agoes and Estralita (2013: 10) are as follows: "Tax accounting is determining the amount of tax payable based on financial reports that have been prepared by the company".

\section{MSMEs Taxpayers}

MSMEs taxpayers according to Law no. 20. Year 2008 concerning MSMEs, namely productive micro, small and medium enterprises owned by individuals and / or entities that meet the requirements based on this law. MSMEs taxpayers are subject to a final income tax of $0.5 \%$ within a certain period.

\section{Tax Evasion}

According to Palowa, A. A., Nangoi, G. B., \& Ger Sungai, N. Y. (2018). Tax Evasion, namely tax evasion, is the active effort of taxpayers in terms of reducing, eliminating, illegal manipulation of tax debts or escaping and not paying taxes as already owed according to statutory regulations. 


\section{RESEARCH METHODOLOGY}

Types of research. Judging from the type of data, the research approach used in this study is a qualitative approach. According to Moleong (2011: 6), qualitative research is research that aims to understand the phenomena of what is felt by research subjects, for example, behavior, perceptions, actions and others as a whole and with descriptions in the form of words and language, in a context. experience and by making use of various research methods. The data used in this research is qualitative. The qualitative data in this study are the answers of the people of City $\mathrm{X}$ about the tax evasion action.

\section{Data Source}

Primary data is data that refers to the information obtained by the researcher itself related to the interest variable for research purposes. Primary data sources are individual informants, focus groups, the internet can also be a primary data source if questionnaires are distributed via the internet (Uma Sekaran, 2011). In this study, researchers focused on taxpayers with the following criteria: (1) who already have income through business activities and have met the requirements to be taxed; and (2) knowing about the tax evasion action.

\section{Data Collection Technique}

The data collection techniques in this study are as follows:

1. Documentation. Documentation is used to collect data and then it is reviewed. The data documented in this study is an overview of City X.

2. Interview. The questions in this study refer to the definition of tax evasion, namely the act of reducing, eliminating, and illegal manipulation of the tax burden to find out about the factors that drive these actions.

3. Observation. Researchers observe all symptoms or phenomena that occur on the object of research in order to match the state of the object of research with the acknowledgment of the informants.

\section{Method of Analysis}

In this study will analyze:

1. Factors that encourage tax evasion in the form of reducing the tax burden.

2. Factors that encourage tax evasion in the form of eliminating the tax burden.

3. Factors that encourage tax evasion in the form of illegal manipulation of the tax burden.

\section{Analysis Process} as follows:

In this research, the researcher will carry out a series of data analysis processes. The data analysis process in this study is

1. The first stage. Researchers collect and analyze the data needed in this study. The data were obtained through direct interviews and documentation to the informants of MSMEs taxpayers in City X. These data are in the form of recognition, views on the factors that drive tax evasion, as well as suggestions from informants who are able to overcome tax evasion actions.

2. The second stage. The results of this analysis will be discussed and then compared with the applicable tax regulations, the theory that supports the importance of paying taxes and previous research. The purpose of this step is to find out the public's view of whether tax regulations are still heavy or not and to know the personal attitudes of MSME taxpayers regarding the factors behind the MSMEs taxpayers in taking tax evasion actions.

3. The third stage. Researchers provide conclusions on the results of the discussion and comparisons that have been carried out in the previous stage.

4. The fourth stage. If the results of the analysis of the factors that drive tax evasion actions on taxpayers in City X have been collected properly and these factors are found, the researcher will provide suggestions through the researcher's own analysis as well as suggestions given by the informants in this study to overcome the action. tax evasion on taxpayers in City X. The purpose of this step is to assist the government in evaluating tax systems and regulations related to the tendency of taxpayers to avoid taxes.

\section{RESULTS AND DISCUSSION}

\section{Result}


Factors That Encourage Action to Reduce Tax Burden. Based on interviews conducted with Mr. Thomas F., who owns a chicken farming business, he acknowledged that the tax evasion action in the form of reducing the tax burden by MSME taxpayers was because the tax burden was too high. As happened in this informant's business, that the business the informant built used a bank loan where every period he got a little profit, even almost lost. Mr. Thomas also said that the tax evasion action occurred because the government did not know it. The same thing was said by the informant Mr. Riangto B., who has a business of buying and selling cellphones, pulses, and cellphone accessories, that the tax evasion action in the form of reducing the tax burden arises because the tariff burden factor is considered too high.

Therefore this informant does not report his income. Sales that do not reach the target are things that feel heavy by Mr. Riangto B. Another informant who owns a restaurant business, Mr. Roni, through direct interviews gave the opinion that tax evasion measures in the form of reducing tax burdens are due to economic factors. As happened in the informant's business, there needs to be a provision for income to pay employee salaries.

\section{Factors That Encourage Action to Eliminate Tax Burden.}

According to Mr. Maxi as the owner of the Restaurant, the Tax Evasion action in the form of eliminating the tax burden is based on personal interests and is considered illegal by Mr. Maxi. Mr. Sucipto as a trader gives the same opinion, that the tax evasion action in the form of eliminating the tax burden is based on the urge to enrich oneself and the drive factor to make ends meet. Mr. Riangto B. (cellphone and accessories counter), and Mr. Roni (restaurant owner) also argue that there is an element of economic motivation that underlies a person taking tax evasion in the form of eliminating the tax burden. Mr. Deni (printer shop owner) and Mr. Maxi (taxi driver and canteen owner) argue that the tax evasion action in the form of eliminating the tax burden is based on distrust of the government bureaucracy.

According to Mr. Maxi, rich officials can easily eliminate the tax burden, especially those who are in the middle to lower class society. This informant argues that the tax evasion action occurs because of an element of distrust of the government who practices corruption. This informant felt that looking for money to pay taxes when corruption was rampant was futile. Therefore, this resulted in the reluctance of this informant to take part in following tax obligations. Meanwhile, Mr. Deni (Printer Shop Owner) argues that there is distrust of the government because of the lack of even development. Through direct interviews with the owner of the chicken farm, Mr. Thomas F., the tax evasion action is in the form of eliminating the tax burden due to the insignificant profit factor. As happened to the business of Mr. Thomas F. who almost lost his business. The majority of other informants said that the tax evasion action in the form of eliminating the tax burden was based on economic factors and personal interests to enrich oneself.

\section{Factors That Encourage Illegal Manipulation Actions Of The Tax Burden.}

Through a direct interview with Mr. Roni (the restaurant owner), tax evasion in the form of illegal manipulation of the tax burden occurs because of the need for evidence because there are many lost invoices which will affect their spending and income. in order to cover the absence of invoices, this informant creates fake invoices / notes. Other opinions came from 4 (four) other informants who responded about the factor of a person committing illegal manipulation practices of the tax burden, namely the dishonest behavior of that person and the inconvenience of the existing rates. 1 (one) other informant said there was an economic factor that was the driving force, 1 (one) other informant argued that the factor for a taxpayer to take tax evasion in the form of illegal manipulation was distrust of the government bureaucracy.

\section{Discussion}

\section{Factors That Encourage Action to Reduce Its Tax Burden.}

The form of reducing the tax burden illegally is to report sales that are smaller than they should be and inflate company costs by imposing fictitious costs, Mentari, A. (2017). Reducing the tax burden can be done properly if we comply with existing regulations. A company can do tax planning in order to reduce the tax burden that is considered too high. Tax planning aims to manipulate so that the tax burden (tax burden) can be reduced as low as possible by using existing regulations to maximize income after tax (after tax return), because tax is an element of reducing profit available, both to be distributed to shareholders and to be reinvested (Suandy, 2011: 7). By utilizing loopholes in statutory regulations, taxpayers can take legal tax avoidance. However, it is not uncommon for taxpayers to take the wrong path and commit illegal acts called tax evasion. In connection with this research, there are 8 (eight) informants in City X, where there are more than 1 (one) factors that encourage taxpayers to take tax evasion actions in the form of reducing the tax burden. 3 (three) informants argued that the action was based on a high tax burden factor, 4 (four) informants said the underlying economic factors, 2 (two) informants said the taxation system was complicated, 1 (one) informant said there was a factor of government indecisiveness, 1 (one) informant said that the factor of distrust of the government bureaucracy encourages someone to take tax evasion action in the form of reducing the tax burden.

If we review the existing rules, namely Regulation of the Minister of Finance Number 182 / PMK.03 / 2015 Article 2 paragraphs 1 and 2, entrepreneurs who have met the subjective and objective requirements are required to report income and pay according to the tax owed without reducing the tax burden. A taxpayer who has a business activity and has income from the business he runs, needs to be filed by a taxpayer, even though the profit is small. The rates set by the government to MSME taxpayers are referred to in this study: 
1. $0.5 \%$ of gross circulation for MSME taxpayers with a gross turnover of less than Rp. 4,800,000,000.

2. Progressive tax rate article 17 for MSME taxpayers who get salaries, honorarium wages, and so on.

3. Restaurant tax $10 \%$ of the food price for restaurant entrepreneurs.

From this research it can be seen that the tax rate below $1 \%$ or any form of tax liability reduction facilities cannot guarantee that the public will report their tax burden without legally reducing the tax burden. Increasing taxpayer compliance so as not to reduce their tax burden is a difficult thing, why is that? Carrying out checks on a business takes time and transparency on the part of people who are willing to be examined. Taxpayers who take tax evasion actions in the form of reducing tend to hide the existing evidence. However, reducing the tax burden solely is not to cheat the existing regulations, but the tax burden that is deemed too high or sudden economic needs makes the MSME taxpayers have to spin their brains. If there is a need, then it will encourage the organism to behave or act to obtain the needs needed to carry on its existence as a living being, such as getting greater benefits, the need for a comfortable life, demands from family needs, and so on. (Binarni, 2016) Like the informant Mr. Thomas F. who was forced to reduce and even did not report it because the profit was insignificant.

\section{Factors That Encourage Action to Eliminate Their Tax Burden}

Zain (2008: 49) argues that tax evasion is an effort made by taxpayers to write off tax debts based on applicable provisions as a violation of taxation laws. Informants provide views of the factors that encourage action to reduce their tax burden. There are informants who provide answers to more than 1 (one) factor. The factors that encourage tax evasion action in the form of eliminating the tax burden according to the informants in this study are, 3 (three) informants view that the burden factor encourages the action, 1 (one) informant argues that the taxation system is complicated, 3 (three) informants view the factors economy that drove the action, 3 (three) informants viewed the self-interest factor that drove the action, and 2 (two) informants viewed the government bureaucratic factor that drove the action. Taxes are mandatory for all people who can afford and earn above average, but currently there are still many people who are basically capable of relatively high tax avoidance (Binarni, 2016). Tax rates are not the only factor that drives people's decisions to pay taxes because basically the tax system as a whole also has a big impact. If, the tax rate on income from one's company is low, but the individual finds a high tax rate on personal income, the taxpayer will perceive the personal tax burden as unfair and choose to write off some of the personal income. (Kurniawati and Toly, 2014).

A more severe form of tax evasion is when the taxpayer does not report his / her income at all (non-reporting of income). As was done by one of the informants in this study, Mr. Maxi. With the presence of Government Regulation no. 23 of 2018 becomes an arena for the expansion of tax subjects, including businesses with even small incomes. However, the government bureaucracy made Mr. Maxi reluctant to take part in the development because he felt that it would be useless if the taxes paid fell into the wrong hands. Indeed, there are still many people who think that the government is a thief of public money. They also think that tax evasion is seen from the current condition of Indonesia, namely the large number of tax officials committing corruption from the proceeds of tax money, thus making taxpayers not willing to pay taxes. Indeed, this fact often disappoints the community.

Often times dishonesty from the government itself is found with a series of history of tax evasion in Indonesia. In reporting their taxes, taxpayers are asked to report their income completely without anything being removed illegally. This has been stated in the General Provisions for Taxation on Tax Crime Article 39 paragraph (1) the deliberate act of submitting an SPT which contains incorrect / incomplete contents. In eliminating the tax burden illegally, the taxpayer will have all income so that when filing the tax return the result will be zero. This has become a gap due to the issuance of the Minister of Finance Regulation (PMK) No. 9 / PMK.03 / 2018 which amend the provisions in PMK No. 243 / PMK.03 / 204 regarding Tax Return.

One of the amendments is the provisions for reporting the Zero Periodic Tax Return. In Article 10 in PMK No. 9 / PMK.03 / 2018, states that taxpayers are exempted from the obligation to report Zero Periodic Tax Returns, except because of the Domicile Certificate, Income Tax Period Article 21 or 26 Tax Returns for the period of December, and the final deduction of Article 21/26 Income Taxpayers who eliminate their tax burdens will always give reasons even though they are clearly eliminating tax burdens and violating existing regulations. Like the informant, Mr. Maxi, who eliminated the tax burden and did not pay it because of the government's bad bureaucracy, such as corruption and uneven development. The attitude of the taxpayer who takes this action is based on circumstances around him. If we talk about the environment where the taxpayers live, the development is not evenly distributed, it will cause a sense of distrust to the government. This has been explained by Purwanto in Rina (2013: 16) in the characteristics of attitude. Attitudes do not stand alone, but always have a certain relationship to an object in other words that attitude is formed and studied or changes always with respect to a certain object that can be clearly formulated.

Factors That Encourage Illegal Manipulation Actions Of The Tax Burden. The tax evasion action in the form of tax burden manipulation received various responses from informants. When asked about the factors that drive tax evasion in the form of illegal manipulation of the tax burden, 2 (two) informants said the action arose because the tax burden was too high, 1 (one) informant argued that the taxation system was complicated, 1 (one) informant believes that the action arises because of the compliance factor, 1 (one) informant is of the opinion that there is a factor of self-interest in the action. 1 (one) informant said there was an economic factor behind the action, and 2 (two) informants were of the opinion that government bureaucratic factors underlie the action. One of the informants gave the opinion that the higher the intelligence of the community towards taxes, the more limiting the community in following tax obligations. 
Another unique thing was said by Mr. Roni through a direct interview, he said that there were forms of manipulation he did in his business. However, he made false evidence to cover the difference in income and existing notes. Mr. Roni suspected that his employees had committed fraud. Of course this will have an impact on Mr. Roni's business income. If we review Article 39A Paragraph (1) of the KUP Law on Tax Crime. Intentionally: Issuing and / or using tax invoices, proof of tax collection, proof of tax withholding, and / or proof of tax payments that are not based on the actual transaction. A fictitious tax invoice is a tax invoice issued not in accordance with the actual transaction or issued by an entrepreneur who has not been confirmed as a Taxable Entrepreneur (Yamin \& Putranti, 2009: 20). Making fictitious invoices is closely related to Value Added Tax. The factors that encourage taxpayers to issue fictitious tax invoices are to obtain personal benefits in the form of Value Added Tax returns (restitution) (Khairani and Mukharromah, 2015: 12).

Illegal manipulation is actually unnecessary if the factor being the high tax burden. Because it has become clear that the tax burden of only $0.5 \%$ of gross circulation is not a large number. However, the views of the people should not be ignored and must become an important focus of the government. Given that the cost of living in society is always dynamic and even constantly increasing, it will encourage someone to take shortcuts that violate existing regulations. Even so, illegal manipulation that leads to acts that violate the law is not a good action regardless of the reasons for it.

\section{CONCLUSIONS AND SUGGESTIONS}

\section{Conclusion}

Based on the results and descriptions, the authors draw conclusions regarding the analysis of the factors that drive tax evasion actions on MSME taxpayers in City X:

1. The factors that encourage MSME taxpayers to take tax evasion actions in the form of reducing the tax burden are the tax burden that is considered too high, the economy, government indecisiveness, compliance and distrust of the government bureaucracy.

2. Factors that encourage MSME taxpayers to take tax evasion actions in the form of eliminating tax burdens are factors of too high tax burden, economy, compliance, and distrust of government bureaucracy.

3. Factors that encourage MSME taxpayers to take tax evasion actions in the form of illegal manipulation of the tax burden are factors of tax burden that are deemed too high, economy, compliance, and distrust of the government bureaucracy.

\section{Suggestion}

The researcher submits suggestions from the research results as follows:

1. In an effort to reduce the number of tax evasion actions in City X District and in an effort to increase local and central tax revenues, the community should help in the form of avoiding and eliminating the tax evasion habit. society must be more open to the government and obey all existing rules. Starting from trying to find out tax information, reporting their income according to what they should be, to becoming a pioneer in paying taxes in the surrounding environment.

2. For tax officials, it is hoped that they will not be tired of providing information to the public and taking action against the perpetrators of tax evasion in City X. Approaching the community is important. Dissemination and counseling on the importance of taxes must continue to be voiced so that people are aware of and willing to work together in development.

\section{REFERENCES}

Dewi, T. J., \& Merkusiwati, N. K. L. A. (2017). Factors that influence taxpayers' perceptions of ethics on tax evasion (tax evasion). E-Journal of Accounting, 18 (3), 2534-2564.

Friskianti, Y., \& Handayani, B. D. (2014). The influence of the self-assessment system, justice, tax technology, and distrust of the tax authorities on tax evasion actions. Accounting analysis journal, 3 (4).

Halim A., and Kusufi S. 2014. Theory, Concepts and Applications of Public Sector Accounting. Salemba Empat: Jakarta.

Fourth, on Law No. 6 of 1983 concerning General Provisions and Tax Procedures to Become Law. December 31, 2008. State Gazette of the Republic of Indonesia of 2008 Number 211. Jakarta.

Khairani, Dienda and Awwaliatul Mukharromah. 2015. Easier, Safer and Convenient with E-Invoice, Inside Tax Ed. 33. Jakarta

Kurniawati, Meiliana and Agus Arianto Toly. Analysis of Tax Justice, Compliance Fees, and Tax Rates on Taxpayers' Perceptions of Tax Evasion in West Surabaya. Tax \& Accounting Review, Vol 4, No 2, 2014. Tax Accounting Program, Petra Christian University Accounting Study Program. Surabaya.

Mardiasmo, 2018. Latest Edition of Taxation. Andi: Yogyakarta.

Moleong, 20011. Qualitative Research Methods. PT. Rosdakarya: Bandung. 
Mentari, A. (2017). Factors Affecting Taxpayers' Perceptions of Ethics on Tax Evasion (Doctoral dissertation, Bengkulu University).

Nastiti, F. A. (2019). Analysis of Factors Affecting Tax Evasion (Case Study of Individual Taxpayers Registered at KPP Pratama Magelang) (Doctoral dissertation, Islamic University of Indonesia).

Palowa, A. A., Nangoi, G. B., \& Ger Sungai, N. Y. (2018). Analysis of Factors that Encourage Tax Evasion Actions on Umkm Taxpayers in Madidir District, X City. GOING CONCERN: JOURNAL OF ACCOUNTING RESEARCH, 13 (04).

Regulation of the Minister of Finance Number 182 / PMK.03 / 2015 of 2015 concerning Procedures for Registration of Taxpayer Identification Numbers, Confirmation of Taxable Entrepreneurs, Abolition of Taxpayer Identification Numbers, and Revocation of Affirmation of Taxable Entrepreneurs. State Gazette of the Republic of Indonesia of 2015 Number 1466. Jakarta

Pratiwi, Rina, Purwanto. 2013. The Influence of the Understanding of Human Rights Materials on the Humane Attitudes of Class VII Students at Smp Negeri 2 Hulu Sungka, North Lampung Regency, Academic Year 2012/2013. Journal of Democratic Culture. Lampung University. Bandar Lampung, University of Lampung

Rahayu, Siti Kurnia. 2010. Indonesian Taxation Concepts and Formal Aspects. Graha Ilmu: Bandung

Now, Uma. 2011. Research Methods for business Edition I and 2. Salemba Empat. Jakarta.

Suandy, Erly. 2011. Tax Planning. Salemba Empat: Jakarta.

Sulistiani, I. (2016). Factors that influence the perception of individual taxpayers doing tax evasion (empirical study on wp op in purbalingga district) (Doctoral dissertation, SEMARANG STATE UNIVERSITY).

Sulistiani, I. (2016). Factors that influence the perception of individual taxpayers doing tax evasion (empirical study on wp op in purbalingga district) (Doctoral dissertation, SEMARANG STATE UNIVERSITY).

Law of the Republic of Indonesia Number 16 of 2009 concerning Stipulation of Government Regulations in Lieu of Law Number 5 of 2008 concerning Amendments

Law of the Republic of Indonesia Number 36 of 2008 concerning the Fourth Amendment to Law Number 7 of 1983 concerning Income Tax. State Gazette of the Republic of Indonesia of 2008 Number 133. Jakarta

Yamin, Luiyanto, Putranti, Titi Muswati. 2009. Tax deviation Model Using Fictitious Tax Invoice. Journal of Administrative and Organizational Sciences, Vol. 16 No. 1. Pg. 1-Yogyakarta.

Zain. 2008. Tax Management 3rd edition. Salemba Empat: Jakarta 